DOI: https://doi.org/10.24867/06HZ02Prole

\title{
IDENTIFIKACIJA NAJČEŠĆIH UZROČNIKA TEŠKIH POVREDA NA RADU U SRBIJI TOKOM 2015. GODINE
}

\section{IDENTIFICATION OF THE MOST COMMON CAUSES OF SERIOUSES INJURIES AT WORK IN SERBIA IN 2015.}

\author{
Lazar Prole, Dragan Adamović, Fakultet tehničkih nauka, Novi Sad
}

\section{Oblast - INŽENEJRSTVO ZAŠTITE NA RADU}

Kratak sadržaj - Bezbednost $i$ zaštita zdravlja na radu jedno je od osnovnih prava svakog čoveka, jer jedino bezbedan rad, zdrava $i$ bezbedna radna sredina omogućavaju produktivan rad. Proučavanje povreda na radu, a posebno teških povreda na radu kao i njihovih uzroka je aktuelan problem jer se analizama dolazi do čitavog niza faktora, koji direktno ili indirektno $u$ jednostavnim ili složenim odnosima doprinose pojavi nesreća na poslu, a time $i$ povređivanju radnika. Analizom dostupnih izveštaja o teškim povredama na radu u Srbiji tokom 2015. godine, identifikovano je 213 teških povreda na radu. U okviru rada su prikazani $i$ statistički analizirani podaci koji ukazuju na dinamiku pojave teških povreda na radu i ukazano je na najčešce uzročnike teških povreda.

Ključne reči: Bezbednost $i$ zaštita na radu, teške povrede, analiza stanja

Abstract - Occupational health and safety represent the fundamental rights of every human being, because only safe work, a healthy and safe work environment enable productive work. The study of injuries at work, and especially serious injuries at work, as well as their causes, is a current problem because analyzes come up with many factors that directly or indirectly in simple or complex relationships contribute to the occurrence of accidents at work, and thus injury to workers. An analysis of available reports on serious injuries at work in Serbia in 2015 identified 213 serious injuries at work. Within the framework of the paper, statistically analyzed data are presented, which indicate the dynamics of the occurrence of serious injuries at work and indicate the most common causes of serious injuries.

Keywords: Occupational safety and health, serious injuries, situation analysis

\section{UVOD}

Kao jedno je od osnovnih prava svakog čoveka, bezbedan rad i zdrava radna sredina omogućavaju produktivan rad i napredak. Rad u humanim uslovima predstavlja zadovoljstvo za svakog pojedinca, ali i uspeh i ponos za organizatora, poslodavca i za društvo u celini.

\footnotetext{
NAPOMENA:

Ovaj rad proistekao je iz master rada čiji mentor je bio dr Dragan Adamović, docent
}

Bezbednost i zdravlje na radu jeste obezbeđivanje takvih uslova na radu kojima se, u najvećoj mogućoj meri smanjuju povrede na radu, profesionalna oboljenja $\mathrm{i}$ oboljenja $u$ vezi sa radom i koji pretežno stvaraju pretpostavku za puno fizičko i socijalno blagostanje zaposlenih.

Međutim, neretko se tokom radnog procesa dešavaju nezgode i povrede zaposlenih. Cilj društva jeste da smanji broj povreda na radu i spreči njihovo nastajanje, a za to je u velikoj meri zaslužno poštovanje pravila o bezbednosti i zaštiti na radu kao i primena mera zaštite.

\section{BEZBEDNOST I ZDRAVLJE NA RADU}

„Bezbednost i zdravlje na radu“ (BZR) je izraz uveden u našu praksu donošenjem Zakona o bezbednosti i zdravlju na radu 2005. godine. Pojam BZR označava organizovanu društvenu aktivnost za obezbeđivanje bezbednih i zdravih uslova rada i potrebne zaštite na radu. Aktivnosti u oblasti bezbednosti i zdravlja na radu značajno doprinose humanizaciji rada i radne sredine, odnosno prilagođavanju rada i uslova rada mogućnostima i potrebama čoveka.

Kod nas se dugo upotrebljavao izraz „Zaštita na radu“ koji je prvi put upotrebljen u Ustavu SFRJ iz 1963. godine, a koristi se i u Ustavu Republike Srbije iz 2006. godine. Tokom razvoja i unapređivanja delatnosti usmerenih na stvaranje zdravih i bezbednih uslova rada upotrebljavani su izrazi poput „bezbednost rada“, „sigurnost rada“, „tehnička i zdravstvena zaštita“, ,higijensko tehnička zaštita (HTZ)“ i drugi. Raznolikost naziva je posledica različitih shvatanja sadržaja delatnosti koja se razvijala uporedo sa razvojem tehnoloških i društvenih uslova i mogućnosti za poboljšavanje uslova rada [1].

\subsection{Zakonska regulativa o BZR u Republici Srbiji}

Bezbednost i zdravlje na radu u Republici Srbiji, uređeni su Ustavom, kao i čitavim nizom zakona, među kojima su: Zakon o radu, Zakon o bezbednosti i zdravlju na radu, Zakon o zdravstvenoj zaštiti, Zakon o penzijskom i invalidskom osiguranju i ostalim podzakonskim propisima. Ustavom Republike Srbije (članom 38., stavom 2. i članom 72. stavom 1.) utvrđeno je pravo zaposlenih na bezbednost i zdravlje na radu.

U skladu sa Ustavom, donet je prvo Zakon o zaštiti na radu koji je važio od 1991. do 2005. godine, kada je na snagu stupio Zakon o bezbednosti i zdravlju na radu, slika 1 . Tako je termin ,zaštita na radu“ promenjen u ,bezbednost i zdravlje na radu“, jer ovaj termin podrazumeva dosta šire polje delovanja zakona, a sve u skladu sa međunarodnim direktivama i konvencijama koje su ratifikovane od strane Republike Srbije [2]. 


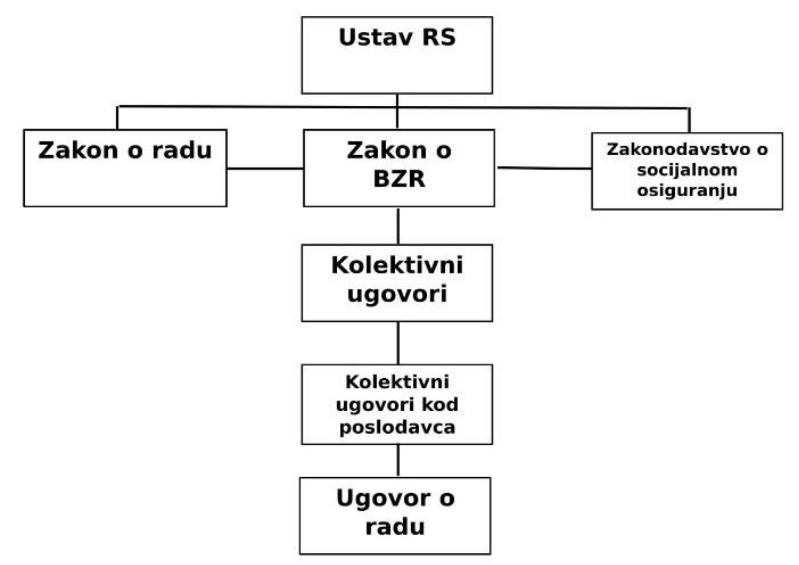

Slika 1. Šema propisa o bezbednosti u zaštiti zdravlja na radu и Republici Srbiji

Zakon je koncipiran uz uvažavanje međunarodnih standarda u oblasti rada. U Zakonu su ugrađene sve odredbe iz konvencija i preporuka Međunarodne organizacije rada (MOR), koje je naša država ratifikovala i direktiva (uputstva) Evropske Unije (EU) koje se odnose na bezbednost i zdravlje na radu. Osnovna dokumenta MOR-a i EU, koja su predpostavka za donošenje Zakona o bezbednosti i zdravlju na radu su: Konvencija MOR-a, br. 155 o bezbednosti i zdravlju u radnoj okolini (1981. godine); Konvencija MOR-a br. 161 o službama za zaštitu zdravlja na radu -službama medicine rada (1985. godina); Konvencija MOR-a br.135, o radničkim predstavnicima (1971. god.); Konvencija MOR-a br.81 o inspekciji rada (1947. god.); Konvencija MOR-a br.187 Promotivna konvencija o bezbednosti i zdravlju na radu (2009. godina); -Direktiva Saveta, 89/391/EEC, od 12 juna 1989. godine o uvođenju mera za podsticanje poboljšanja bezbednosti i zdravlja radnika na radu; Evropska socijalna povelja (1996. godina); Rezolucija Saveta EU, od 21 decembra 1987. godine, o bezbednosti, higijeni i zdravlju na radu (88/S28/01) [3].

\section{POVREDE NA RADU}

Povreda na radu predstavlja neželjeni događaj čija je posledica narušavanje telesnog integriteta radnika. Uz to, svaka povreda nosi u sebi bol koji podnosi povređeni. Inače, povreda na radu je poslednji događaj u lancu čija je prva karika potencijalna opasnost nastala usled delovanja ljudskog i materijalnog faktora. Pod uticajem faktora aktiviranja, potencijalna opasnost prerasta u aktivnu, a aktivna opasnost prerasta u nezgodu delovanjem neposrednih faktora. Ako se svi faktori podudaraju u vremenu, a da se pri tome, podudaranje ne može izbeći, neminovno dolazi do povreda na radu.

Jedan od značajnih faktora $u$ lancu nastanka povreda na radu je vezan za godine života i dužinu radnog staža radnika. Naime, brojna istraživanja u Evropi su pokazala da se na istovrsnim poslovima $\mathrm{i} u$ približno jednakim uslovima rada, mlađi radnici češće povređuju, a da su povrede starijih radnika teže prirode [4].

\subsection{Uzroci povreda na radu}

Pojava i vrsta povreda na radu zavisi od delatnosti o kojoj se radi, pa su tako povrede u teškoj industriji češće nego povrede u lakoj. Broj povreda na radu je u stalnom porastu, a uzroci su mnogobrojni. Neki od njih su:
1) Faktori radne sredine: mikroklima, buka i vibracije, osvetljenje, stanje mašina, alata, uređaja koji se koriste u procesu rada.

2) Socijalno-ekonomski faktori: materijalni status radnika, uslovi stanovanja, način ishrane, prisustvo bolesti, mogućnost zadovoljenja obrazovnih i kulturnih potreba.

3) Ljudski faktor: životno doba, pol, obučenost za radno mesto, radno iskustvo, zdravstveno i emotivno stanje radnika [5].

Smatra se da je ljudski faktor najznačajniji u nastanku povreda uopšte i povreda na radu.

\section{PREGLED I ANALIZA POSTOJEĆEG STANJA U OBLASTI BZR U SRBIJI}

Ključne posledice krize koje su zahvatile Republiku Srbiju su nezavršen proces privatizacije, nelikvidnost, pad proizvodnje i izvoza, povećanje nezaposlenosti i pad životnog standarda. Sva ova negativna kretanja su imala veliki uticaj na socijalno-ekonomsku politiku, pa samim tim i na oblast bezbednosti i zdravlja na radu.

Prethodni period je karakterisalo povećanje broja radno angažovanih lica kod poslodavaca u kraćim vremenskim intervalima; češća promena vrste posla koju obavljaju lica na radu i radnog mesta u okviru kojeg rade, duže zadržavanje na radu, a što ima za posledicu povećanu neopreznost na radu, ignorisanje opasnosti koje se pojavljuju u procesu rada i zanemarivanje rizika usled opasnosti, kao i povređivanje na radu. Strah od gubitka posla se negativno odražava na koncentraciju lica na radu i pažnju u toku rada.

Kao najugroženija privredna grana, odnosno delatnost u kojoj su najčešće opasne pojave kojima su ugroženi život i zdravlje zaposlenih, sa većim brojem povreda na radu i težinom posledica i dalje je građevinarstvo, u kojem se kao izvođači radova pojavljuju poslodavci bez potrebnog poslovnog i tehnološkog iskustva $u$ obavljanju ove delatnosti [6].

\subsection{Pregled povreda na radu u 2015. godini prema delatnosti}

Najveći broj povreda na radu u 2015. godini zabeležen je u delatnostima industrije i rudarstva $(37,31 \%)$, zdravstvene i socijalne zaštite $(11,80 \%)$ i saobraćaja i veza $(6,72 \%)$, slika 2 .

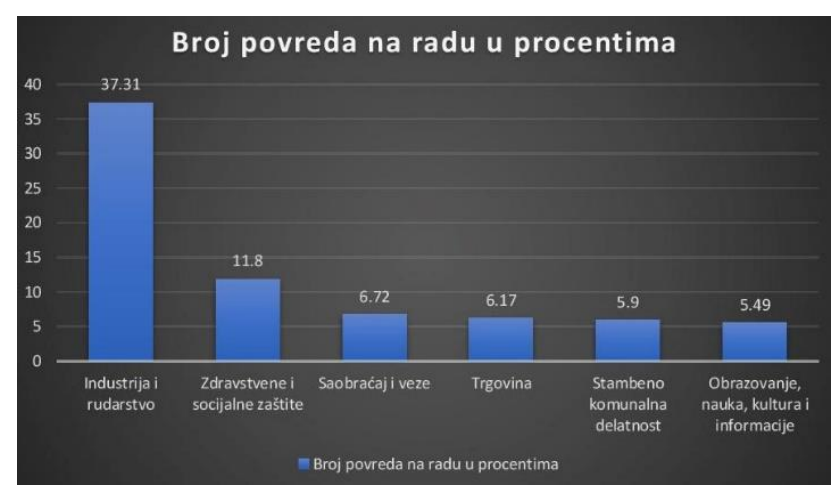

Slika 2. Grafički prikaz broja povreda na radu u procentima prema pretežnoj delatnosti 


\section{ANALIZE TEŠKIH POVREDA}

Posledice nesreće na poslu nisu samo povrede u fizičkom i psihičkom smislu, već i dezorganizacija u radu. Povrede na radu imaju socijalno-medicinski i društveno-ekonomski značaj, jer povlače odsutnost sa posla, a time i manju produktivnost rada, često invaliditet, ponekad i gubitak života, isplatu naknade umesto ličnog dohotka, troškove lečenja, medicinske i profesionalne rehabilitacije i dr., što ima negativnih posledica po pojedinca, njegovu porodicu, radnu organizaciju i društvenu zajednicu u celini. Jasno je da je za smanjenje broja i težine povreda na radu neophodna uspešna prevencija nesreća na radu.

Analiza povreda na radu ima za cilj da otkrije šta je sve prethodilo tom završnom činu. Otuda se i pridaje poseban značaj analizi povreda na radu, jer se na osnovu otkrivenih uzroka mogu preduzeti direktne mere, koje su u stanju da spreče ponovnu nesreću.

Dosadašnje iskustvo kod nas i u drugim zemljama je pokazalo da se analizi nesreća na radu, naročito njihovih uzroka, a još više preduzimanju mera za njihovo otklanjanje ne poklanja odgovarajuća pažnja, pa zbog toga nije moguća potpuna prevencija povreda na radu.

U nastanku teških povreda na radu, smatra se da je ljudski faktor najznačajniji. Na osnovu brojnih analiza povreda na radu, uočeni su izvesni faktori koji imaju značaja pri povređivanju. To su:

- godine starosti,

- dužina radnog staža (iskustvo),

- adaptacija novih radnika ili starih radnika na nove poslove,

- akutne i hronične bolesti,

- stres,

- telesne karakteristike,

- različiti fizički nedostaci,

- motivacija za rad i sl. [7].

\section{REZULTATI I DISKUSIJA}

U okviru ovog rad izvršena je analiza uzročnika teških povreda na radu u Rep. Srbiji na osnovu 213 dostupnih izveštaja o teškim povredama na radu tokom 2015. god. Delatnosti u kojima su se dogodile teške povrede na radu u radnim organizacijama u Srbiji tokom 2015. god obuhvataju:

- poljoprivredu,

- građevinarstvo,

- trgovinu na veliko i malo,

- saobraćaj i skladištenje,

- komunlane delatnosti,

- usluge smeštaja i ishrane,

- umetnost, zabavu i rekreaciju,

- državnu upravu i

- industriju.

$\mathrm{Na}$ osnovu dobijenih rezultata koji su prikazani grafički (slika 3.), najveći procenat radnih organizacija u Srbiji u 2015. godini u kojima su se dogodile teške povrede na radu pripada delatnosti državne uprave $(10 \%)$, obrazovanja (10\%), umetnosti, zabave i rekreacije (10\%), usluga smeštaja i ishrane (10\%), ostalim delatnostima (10\%), zatim zdravstvu (9\%), saobraćaju i skladištenju (8\%), kao i komunalnim delatnostima $(8 \%)$, trgovini na veliko i malo (7\%), građevinarstvu (6\%), a na najmanji broj preduzeća je iz sektora poljoprivrede (1\%) i industrije $(1 \%)$.

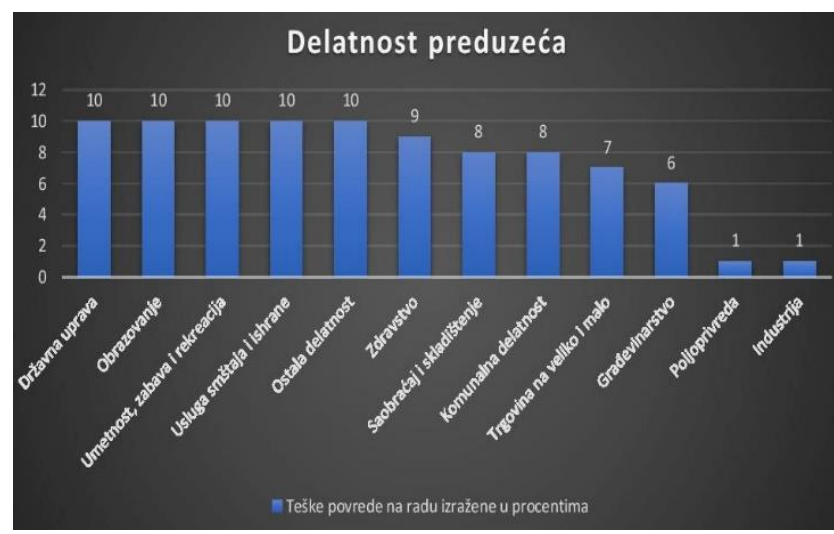

Slika 3. Raspodela delatnosti u Srbiji u 2015. godini u kojima su se dogodile teške povrede na radu

Najveći broj teških povreda na radu dogodio se radnicima sa višim stepenom stručne spreme i to $20-21 \%$ povreda doživeli su radnici sa IV, V, VI i VII stepenom obrazovanja, zatim $12 \%$ onih koji imaju III stepen, i na kraju 3\% radnika sa II stepenom i isti procenat onih sa završenom osnovnom školom (3\%), (slika 4.).

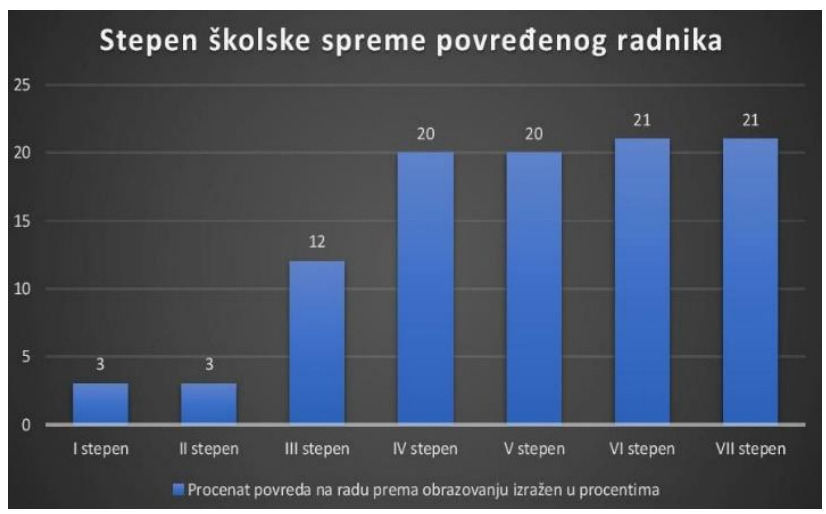

Slika 4. Procenat povreda na radu prema obrazovanju povređenih radnika

Najveći broj teških povreda na radu izražen u procentima desio se u Beogradu (18\%), zatim u Južnom Pomoravlju (13\%), i Šopluku (13\%), Rasini i Toplici (12\%), Podrinju (11\%), zatim u Raškoj (10\%), Timoku i Braničevu (10\%), dok je najmanji procenat zabeležen u Šumadiji (8\%) i Vojvodini (5\%), (slika 5.).

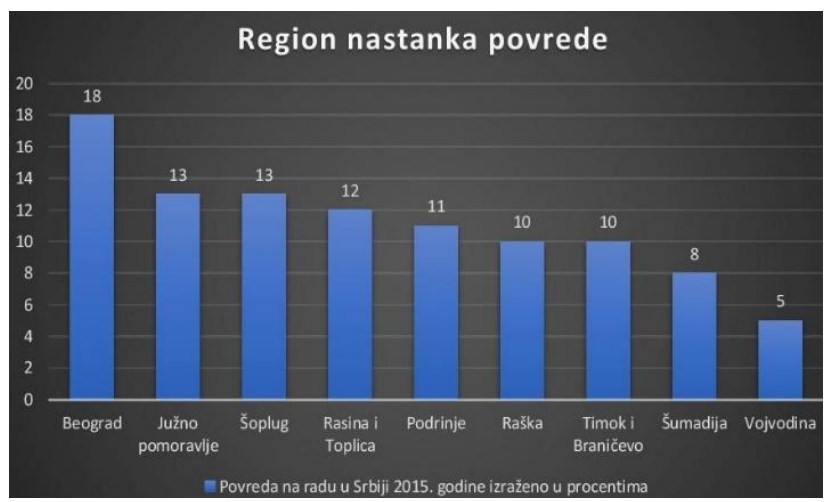

Slika 5. Procenat povreda na radu na region države Srbije u 2015. godini 


\section{ZAKLJUČAK}

Pravo na bezbedan i zdrav rad na radnom mestu je osnovno ljudsko pravo. Ovo pravo mora da se poštuje na svakom nivou razvoja $i \mathrm{u}$ različitim ekonomskim uslovima. Poštovanje ovog ljudskog prava je obaveza svih koji se bave problematikom bezbednosti zdravlja na radu, a ulaganje u prevenciju je moguće i potrebno, što je uslov za održivi ekonomski razvoj. Tamo gde su investicije uložene u prevenciju rizika od povreda na radu i profesionalnih bolesti dolazi do do značajnih društvenoekonomskih koristi i u proseku se uštedi znatno više novca nego što je uloženo u prevenciju.

Povrede na radu su redovna i prateća pojava svake ljudske delatnosti i jedan od glavnih zdravstvenih, ekonomskih i privrednih problema modernog društva. Njihove posledice ne pogađaju samo povređenog radnika već i njegovu porodicu, radnu organizaciju i celokupno društvo. Oštećenja zdravlja, umanjenje ili gubitak radne sposobnosti, materijalni troškovi zbog nadoknade bolovanja, lečenja, rehabilitacije, invalidnosti, umanjenje životnih aktivnosti, poremećaji u porodici, ometanje radnog procesa, opadanje produktivnosti i kvaliteta rada izazvano povredama na radu čine problem profesionalnog traumatizma veoma aktuelnim [8]. I pored preduzimanja sveobuhvatnih mera za siguran i bezbedan rad, sprovođenjem svih mera zaštite, u pojedinim situacijama dolazi do povećanja rizika i često do incidenta, jer zataji ljudski faktor .

\section{LITERATURA}

[1] Ugarak D. 2010. BZR, Pravni izvori i nacionalni sistem BZR, Beogradska politehnika, Beograd

[2] Ilić, A. 2006. Bezbednost i zdravlje na radu, Granski sindikat metalaca „Nezavisnost", Beograd

[3] Božić-Trefalt V. i dr. 2012. Osnove iz bezbednosti i zdravlja na radu i zaštite od požara. Visoka tehnička škola strukovnih studija, Novi Sad
[4] Medak, I. Spasić, D. Avramović, D. 2012. Povrede na radu prema godinama života i dužini radnog staža povređenih radnika, Menadžment i sigurnost - M\&S 2012: „Upravljanje ljudskim resursima i sigurnost", str. 459-472

[5] Salić, T. 2017. Zloupotreba povreda na radu, Udruženje Klaster komora za zaštitu životne sredine i održivi razvoj, Zrenjanin

[6] Stanković, M. 2016. Prilog povećanju bezbednosti na radu sa posebnim osvrtom na rad sa dizalicama, magistarska teza, Univerzitet u Kragujevcu, Fakultet za mašinstvo i građevinarstvo, Kraljevo

[7] Drobnjak, R. Drobnjak, P. Vasović V. 2011. Bezbednost i zdravlje na radu u valjaonici bakra ad Sevojno u 2010. godini. U: Rizik i bezbednosni inženjering, zbornik radova 7 . međunarodnog naučnog savetovanja. Visoka tehnička škola strukovnih studija u Novom Sadu

[8] Keogh. J.P. Nuwayhid, I. Gordon, J.L. Gucer, P.W. 2000 The impact of occupational injury on injured worker and family: outcomes of upper extremity cumulative trauma disorders in Maryland workers. Am J Ind Med 2000; 38(5): 498-506.

\section{Kratka biografija:}

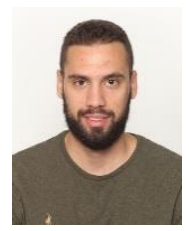

Lazar Prole rođen je u Novom Sadu 20.09. 1993. Završio je Gimnaziju „Isidora Sekulić” u Novom Sadu. Diplomirao je 2018. godine na Fakultetu tehničkih nauka u Novome Sadu, smer inženjerstvo zaštite na radu. Upisao je master studije iz iste oblasti 2018. godine i odbranio master rad 2019. godine. kontakt: mpadaptacija@gmail.com

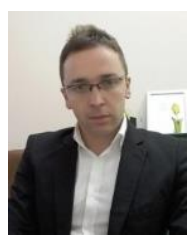

Dragan Adamović rođen je 1976. Godine u Subotici. Doktorirao je na Fakultetu tehničkih nauka i izabran u zvanje docenta 2015. godine. 